\title{
Development and Quality Analysis of a Direct Solar Dryer for Fish
}

\author{
Surajudeen Olanrewaju Obayopo, Oluwasanmi Iyiola Alonge \\ Department of Mechanical Engineering, Obafemi Awolowo University, Ile Ife, Nigeria \\ Email: obayopos@oauife.edu.ng,sirajolanre@yahoo.com
}

How to cite this paper: Obayopo, S.O. and Alonge, O.I. (2018) Development and Quality Analysis of a Direct Solar Dryer for Fish. Food and Nutrition Sciences, 9, 474-488.

https://doi.org/10.4236/fns.2018.95037

Received: March 6, 2018

Accepted: May 14, 2018

Published: May 17, 2018

Copyright $\odot 2018$ by authors and Scientific Research Publishing Inc. This work is licensed under the Creative Commons Attribution International License (CC BY 4.0).

http://creativecommons.org/licenses/by/4.0/

\section{(c) (i) Open Access}

\begin{abstract}
The study investigates drying characteristics of common species of fish in the tropics, catfish (Clarias gariepinus) and tilapia fish (Oreochromis niloticus) using a direct solar dryer. The drying process was carried out during the dry and wet season under natural $(0 \mathrm{~m} / \mathrm{s})$ and forced convective drying $(1.5 \mathrm{~m} / \mathrm{s}$, $2.5 \mathrm{~m} / \mathrm{s}, 3.5 \mathrm{~m} / \mathrm{s}$ fan speed). Results obtained showed that the drying air attained by the dryer was satisfactory and the maximum temperature difference between the dryer and the ambient temperatures was $35^{\circ} \mathrm{C}$. The moisture content of the dried samples was $13.97 \%$ for catfish and $13.35 \%$ for tilapia fish during dry season and during the wet season it was $15.68 \%$ for catfish and $14.9 \%$ for tilapia fish while for the open sun dried samples it was $21.7 \%$ for catfish and $17.0 \%$ for tilapia fish. Maximum drying efficiency of $74.3 \%$ was recorded for the dryer during dry season and the dried samples at $3.5 \mathrm{~m} / \mathrm{s}$ fan speed were better in drying rates. The proximate compositions of the fish before and after drying were determined. There was significant difference in proximate composition before and after drying $(\mathrm{P}<0.05)$ and no significant difference in proximate composition at fan speeds considered for both fish species $(\mathrm{P}<0.05)$.
\end{abstract}

\section{Keywords}

Solar Dryer, Fish, Moisture Content, Drying Rate and Drying Efficiency

\section{Introduction}

Fish is one of the most diverse groups of animals known to man with more than 20,500 species in existence [1]. However, out of these species the catfish and tilapia fish (Figure 1) are the most cultured in the tropics. Fish flesh is a source of top quality protein, and for many in the less developed parts of the world it represents a significant proportion of the animal protein in their diet, either as 


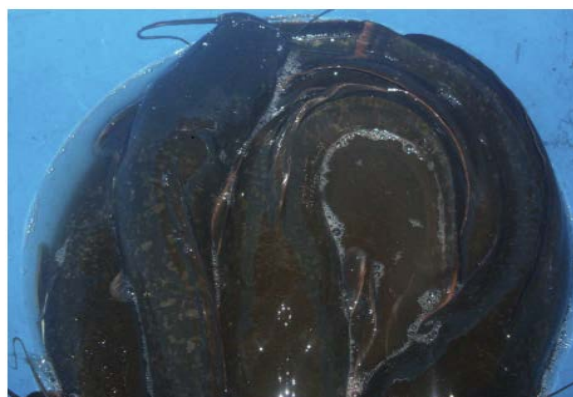

(a)

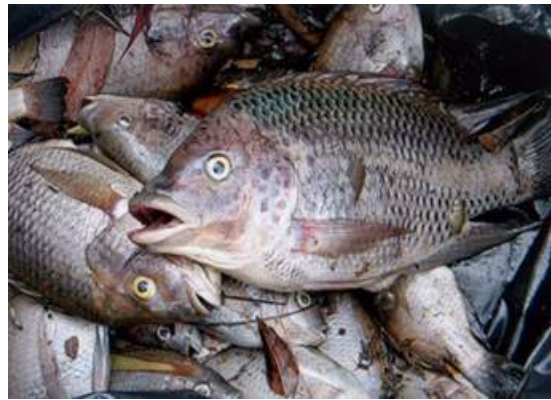

(b)

Figure 1. Picture of (a) catfish and (b) tilapia fish.

fresh fish or cured in a variety of ways, such as smoking, salting and drying. However, despite its importance in contributing to national economies, health, food security and in improving the livelihoods of many artisanal fisher men in many developing countries, up to $50 \%$ of the fish harvested are wasted [2]. This is because fish is harvested at an average high moisture content of $5 \mathrm{~kg} / \mathrm{kg}$, dry basis [3] and if unpreserved, it undergoes rapid spoilage, even without external contamination, in less than $24 \mathrm{~h}$ of capture and becomes unfit for human consumption [4]. Thus there is need for processing techniques for its preservation.

The traditional methods of drying fish (Open sun drying and smoking) are not hygienic. The open drying process usually leads to the deterioration of the products because of many detriments. Smoking contributes to environmental degradation since it uses biomass and also introduces cancer causing substances in fish flesh since smoke contains Poly Aromatic Hydrocarbons (PAH) which are carcinogenic.

Researchers have in recent times developed different solar dryers to alleviate the problems associated with traditional methods with justification that: they will be more effective than open sun drying, have lower operating costs than mechanized dryers, can be constructed with locally available materials and can be useful in areas where fuel or electricity are expensive. Mustayen et al. [5] presented a review on performance study of different solar dryers. The paper presents the state of various kinds of solar dryers that are widely used today. The indirect, direct, and mixed mode dryers that have shown potential in drying agricultural products in the tropical and subtropical countries are discussed. The natural convection solar dryers suffer from the limitations due to extremely low buoyancy induced air flow inside the dryers [6] [7]. The high weather dependent risk and lack of modeling of the dryer toward parameter optimization for optimal drying performance before actual production of prototype stimulated Alonge et al. [8], to carry out CFD analysis on a direct solar dryer with a fan providing the air flow required to remove the evaporated moisture. The results indicate that optimal length of $70 \mathrm{~cm}$ and height of $40 \mathrm{~cm}$ at breath $60 \mathrm{~cm}$ (without the lagging thickness) with tray position at $25 \mathrm{~cm}$ away from the base of the dryer will produce better drying result. Several works have been carried out to study the drying characteristics of fish using electric powered and solar dryers 
[9]-[14]. The objective of this work was to investigate the performance of the direct solar dryer using natural and forced convective methods for drying of catfish and tilapia fish.

\section{Materials and Methods}

\subsection{Description of the Drying System}

The experimental dryer was developed and designed using dimension by Alonge et al. [8] as shown in Figure 2 and Figure 3 show the exploded view of the dryer. The dryer was made with locally available materials such as galvanized sheet, glass sheet, and fibre glass. The drying chamber was double walled insulated with fiber glass of $5 \mathrm{~cm}$ thick to prevent energy losses. A $12 \mathrm{~V} \mathrm{DC}$ fan was attached to the dryer to induce force convection and this was connected to speed

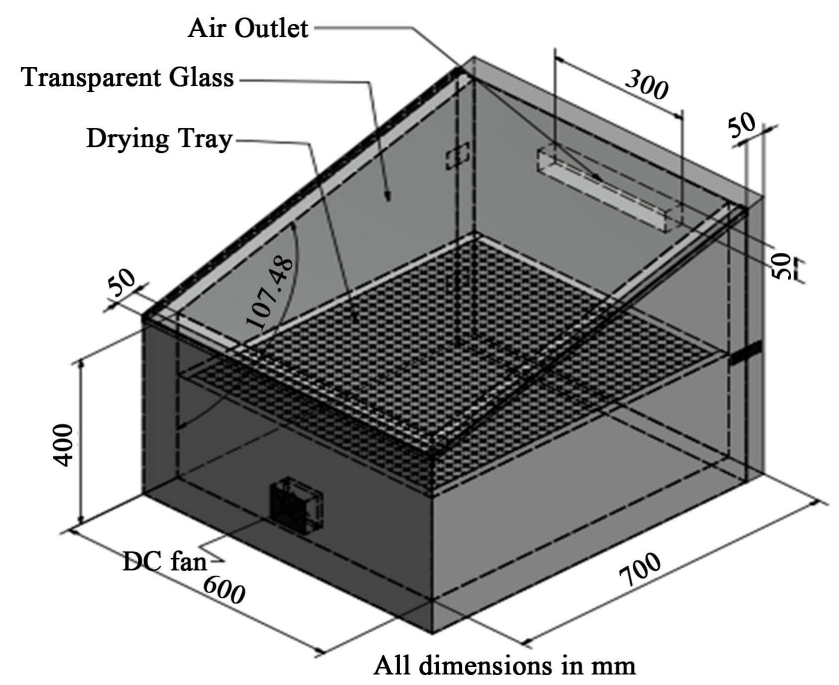

Figure 2. Experimental dryer.
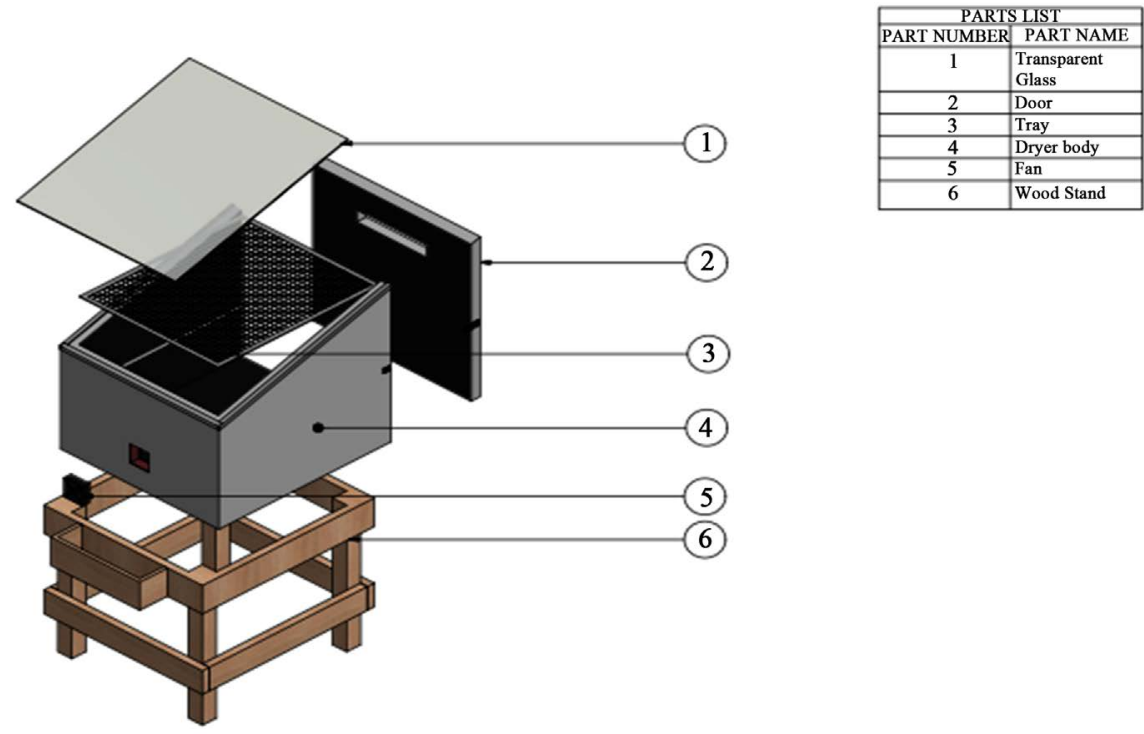

Figure 3. Exploded view of the solar dryer. 
regulator which was connected to $12 \mathrm{~V}$ DC battery. The fan has enough power to provide air velocity needed and to overcome the back up pressure cause by the tray and can be easily control to compensate for temperature variation. The inner wall was painted with coal tar for enhanced absorption and emission of solar energy.

The best stationary orientation is due south in the northern hemisphere and due north in southern hemisphere (Alonge et al., 2017). Therefore the dryer in this work was oriented facing south.

\subsection{Materials Specification}

The quantity of heat transferred in the internal section, $Q$ was calculated using Equation (1). The thermal conductivity $(k)$ of the galvanized sheet metal is 0.36 $\mathrm{W} / \mathrm{mK}$. The thickness of the galvanized sheet was $1 \mathrm{~mm}$.

Fiber glass was used as a lagging material for the dryer with the following properties according to Owolarafe et al. [15]: thermal conductivity (0.032 $\mathrm{W} / \mathrm{mK})$, embodied carbon $\left(1.35 \mathrm{CO}_{2} / \mathrm{kg}\right.$ ), embodied energy $(28 \mathrm{MJ} / \mathrm{k})$. The lagging (Insulation) thickness was calculated using Equation 1 and the widest wall of the dryer was considered $(Q) . T_{1}$ and $T_{2}$ were assumed to be the maximum expected temperature and the ambient temperature, respectively $\left(60^{\circ} \mathrm{C}\right.$ and $27^{\circ} \mathrm{C}$ ) and $K_{f}$ is the thermal conductivity of fiber glass. $X_{L}$ is the thickness of the lagging and was calculated to be $5.2 \mathrm{~cm}$.

$$
Q=\frac{K_{f} A\left(T_{1}-T_{2}\right)}{X_{L}}
$$

Galvanized wire mesh was used for the tray considering the capability to carry $3.5 \mathrm{~kg}$ of fish (with an average length and thickness of $30 \pm 1.46 \mathrm{~cm}$ and $4 \pm 0.15$ $\mathrm{cm}$, cut into fillets) without sagging and retain the fish after drying and the aperture wide enough to allow free flow of heated air. $2 \times 1$ inches wire mesh was joined together with chicken wire mesh of $50 \mu \mathrm{m}$ was used.

\subsection{Theoretical Analysis}

The mass of moisture to be removed was calculated using Equation (2). $M_{i}$ is the initial mass of fish, $M_{o}$ is the initial moisture content and $M_{f}$ is the final moisture content.

$$
M_{w}=\frac{M_{i}\left(M_{o}-M_{f}\right)}{\left(100-M_{f}\right)}
$$

According to Bala and Mondol [10], fresh fish contains up to $80 \%$ of water and to prevent mould growth during storage, moisture content must be reduced to $15 \%$ (wet basis).

For simplicity, the quantity of air needed for the drying was calculated by considering the drying process on the psychometric chart as shown in Figure 4. If the average ambient air temperature $T_{a}\left(27^{\circ} \mathrm{C}\right)$ and ambient relative humidity $R H_{a}$ (75\%) is heated to temperature $T_{B},\left(60^{\circ} \mathrm{C}\right)$ then $R H_{a}$ will reduce to 


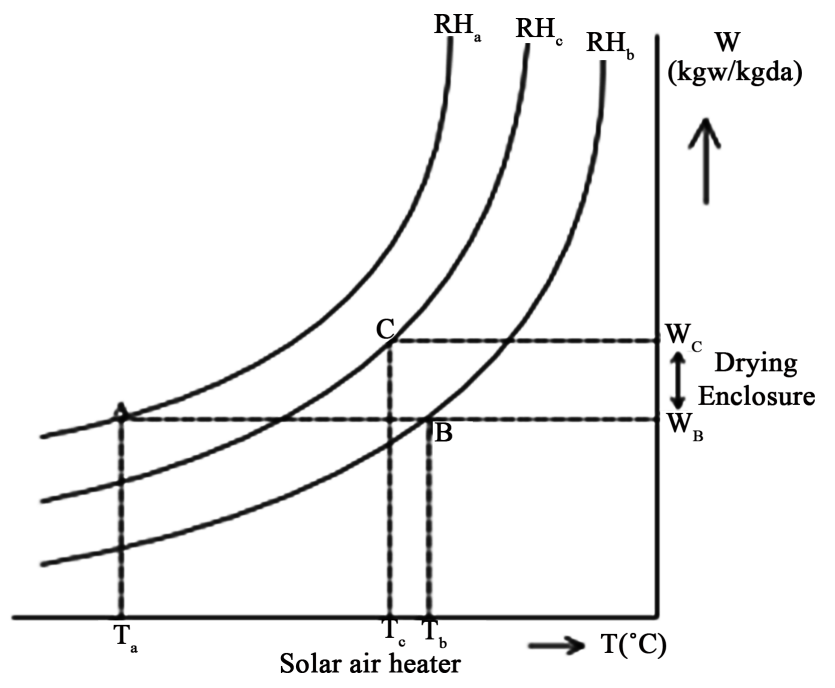

Figure 4. Illustration of the drying process on psychometric chat.

$R H_{b}$. This heated air is used to remove moisture, until equilibrium $\left(R H_{c}\right)$ is reached. The temperature of the drying air will reduce from $T_{B}$ to $T_{C}$ and the humidity ratio $W$, will increase from $W_{B}$ to $W_{C}$ with increment of $\Delta W_{C B}=W_{C}-W_{B}$. It follows therefore that the mass of air required to remove moisture in the drying process is represented in Equation (3). $n$ is the pickup factor. Using $n$ value of 0.2 (Considered appropriate for fish from literature).

$$
M_{a}=\frac{M_{W}}{\left(\Delta W_{C B} \times n\right)}
$$

The heat quantity required to evaporate the water is calculated using Equation (4), Owolarafe et al. [15]:

$$
Q=m_{w} \times h_{f g}
$$

The latent heat of vaporization $\left(h_{f g}\right)$ is calculated using Equation (5), by Youcef-Ali et al. [16]:

$$
h_{f g}=4.168 \times 10^{3} \times\left[597-T_{p r}\right]
$$

where $T_{p r}$ is the product temperature, $\left(T_{p r}=26^{\circ} \mathrm{C}\right)$. The total heat energy, $E(\mathrm{KJ})$ required to evaporate water is calculated using Equation (6). Where $h_{f}$ and $h_{i}$ are the final and initial enthalpy, respectively.

$$
E=m_{a}\left(h_{f}-h_{i}\right)
$$

The enthalpy $(h)$ of moist air in $\mathrm{j} / \mathrm{kg}$ dry air at temperature $T\left({ }^{\circ} \mathrm{C}\right)$ can be approximated using Equation (7) as given by Brooker et al. [17]:

$$
h=1006.9 T+w(2512131.0+1552.4 T)
$$

Equilibrium relative humidity is calculated using sorption isotherms equation given by Hernadez et al. [18] in Equations (8) and (9). $a_{w}$ is the water activity and $M$ is the moisture content in dry basis.

$$
\mathrm{ERH}=100 a_{w}
$$




$$
a_{w}=1-\exp [-\exp (0.914+0.5639 \ln M)]
$$

The loss in weight of the fish samples was recorded using electronic digital balance. The recorded losses in weight of drying fish were converted into corresponding moisture contents on wet basis using Equation (10), as reported by Ekechukwu [19]. $W_{t w b}$ is the moisture content on wet basis, $W_{t}$ is the weight at a time interval, $M_{o w b}$ is the initial moisture content on wet basis and $W_{o}$ is the original weight.

$$
W_{t w b}=1-\left[\frac{\left(1-M_{o w b}\right) \times W_{o}}{W_{t}}\right]
$$

The drying rate is a fundamental parameter in the evaluation of drying process and was calculated using Equation (11). $\Delta M$ is the change in weight and $\Delta t$ is the time interval

$$
D R=\frac{\Delta M}{\Delta t}
$$

\subsection{Experimental and Drying Procedure}

Solar drying was carried out in the dryer during the dry and wet season of the year. Drying was done at different fan speeds $[0 \mathrm{~m} / \mathrm{s}$ (natural convention), 1.5 $\mathrm{m} / \mathrm{s}, 2.5 \mathrm{~m} / \mathrm{s}$, and $3.5 \mathrm{~m} / \mathrm{s}$ ] during the dry season and comparison was made with the traditional open sun method. Drying was only carried out at 1.5 and $3.5 \mathrm{~m} / \mathrm{s}$ fan speed to check how the dryer will perform with forced air during the wet season.

Catfish and tilapia fish were procured from the local market at Ile-Ife. The average weight, length and thickness of the catfish were $353 \pm 15.67 \mathrm{~g}, 30 \pm 1.46$ $\mathrm{cm}$ and $4 \pm 0.15 \mathrm{~cm}$, respectively. The fish were beheaded and cut into fillets [Head: $8 \mathrm{~cm}$ long, Middle (5 pieces): $3 \mathrm{~cm} \times 3.5 \mathrm{~cm}$ and Tail: $7 \mathrm{~cm} \times 2 \mathrm{~cm}$ ] for effective drying and this made it easy to eviscerate. For the tilapia, the average weight, length and thickness were $132 \pm 13.02 \mathrm{~g}, 14 \pm 0.5 \mathrm{~cm}$ and $3.5 \mathrm{~cm}$, respectively. The fish were also beheaded, descaled, cut into fillets [Head: $4 \mathrm{~cm}$ long, Middle (3 pieces): $2.5 \mathrm{~cm} \times 2.5 \mathrm{~cm}$, Tail: $4 \mathrm{~cm} \times 2 \mathrm{~cm}$ ] and eviscerate. The initial moisture content and weight after evisceration were measured using LCD, 0 $1000 \mathrm{~g}$ weighing balance before the experimental run.

The drying parameters were monitored throughout the drying period between 9:00 am and 5:00 pm each day at two hours intervals. The air temperature was measured using $\mathrm{k}$ type TP-01 thermocouple together with S220-T8 data logger, the relative humidity and fan speed was monitored using Lutron LM-8010 multimeter. The fish samples were taken out of the dryer at the end of the drying process each day and spread on a table at room temperature because of high humidity observed in the dryer at night which can lead to moisture reabsorption but no appreciable moisture was lose to the atmosphere (about 4\%) with the difference decreasing with increase in drying days and on the third and fourth day, no significant difference was observed. The drying process of each of the expe- 
rimental run was ended when the change in weight was no longer significant.

\subsection{Performance Evaluation of the Solar Dryer}

The system drying efficiency of the dryer is a factor that describes how effectively the input energy to the drying system was used by the dryer for product drying. The efficiency was calculated using Equation (12) given by Sengar et al. [11]. $W$ is the weight of water evaporated from the fish $(\mathrm{kg}), L$ is the latent heat of vaporization of water, $A_{C}$ is the surface area of the collector, $I$ is the incident radiation $\left(\mathrm{W} / \mathrm{m}^{2}\right)$ and $t$ is the time (hour).

$$
\eta=\frac{W \cdot L}{A_{C} \cdot I \cdot t} \times 100
$$

\subsection{Proximate Analysis}

The proximate composition was carried out for the fish samples dried during the dry season at food science laboratory as described by AOAC [20]. Each analysis was carried out in duplicate before and after the drying process. Moisture content was measured by weighing the differences before and after drying and this was done at $105^{\circ} \mathrm{C} \pm 1{ }^{\circ} \mathrm{C}$ until no constant weight was obtained. The total protein was determined using the Kjeldahl method. The ash content was determined by using drying ash procedures using muffle furnace (Carbolite AAF1100, United Kingdom). Carbohydrate content was obtained by difference between the addition of other proximate chemical components and 100 .

\subsection{Statistical Analysis}

The design was randomized. Proximate composition analysis was replicated two times $(n=2)$. Results presented are means values of each determination \pm standard deviation. Analysis of variance was performed by using one way and two way ANOVA procedures and the significance was defined at $95 \%$ confidence level $(\mathrm{P}<0.05)$.

\section{Result and Discussion}

\subsection{General Observation}

The variation of moisture content with time at different fan speeds during the dry and wet season for the two fish species considered were presented in Figures 5-8. Fish samples dried using the dryer had initially high drying rates which declined drastically as the drying process continued. This is due to water movement controlling the drying rate from the beginning of the drying process [21] and the initial moisture content of the samples also affecting the drying rate. Consequent increase in drying time resulted in reduction in drying rate of fish samples in the dryer and this is in conformity with previous study carried out on drying of agricultural product [22] [23]. However, values obtained showed that the drying rate of fish is affected by the natural characteristics of the fish, high 


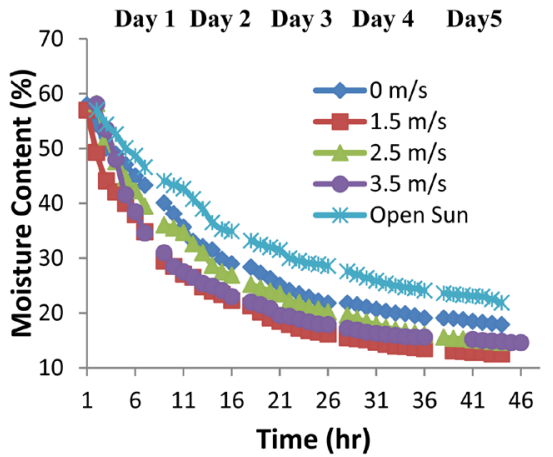

(a)

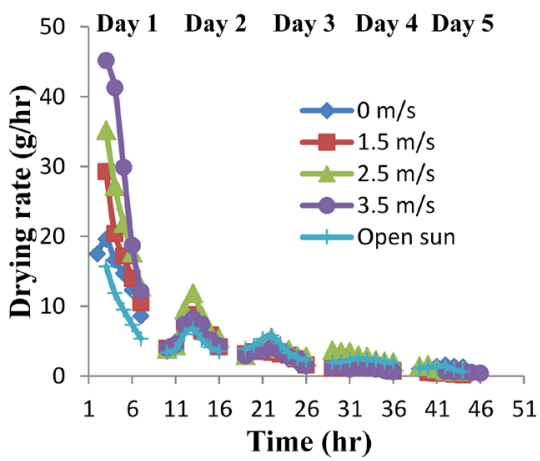

(b)

Figure 5. Variation of catfish (a) moisture content (b) drying rate with time during dry season.

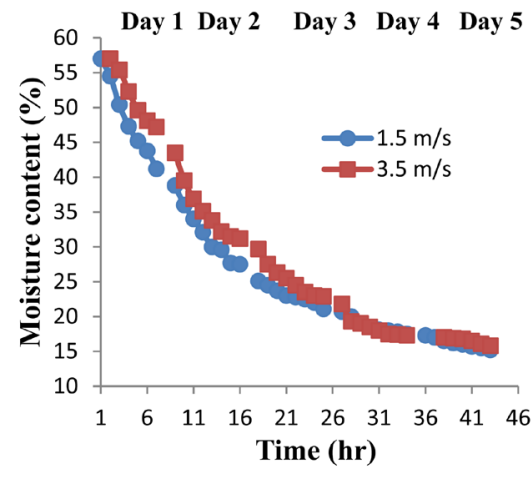

(a)

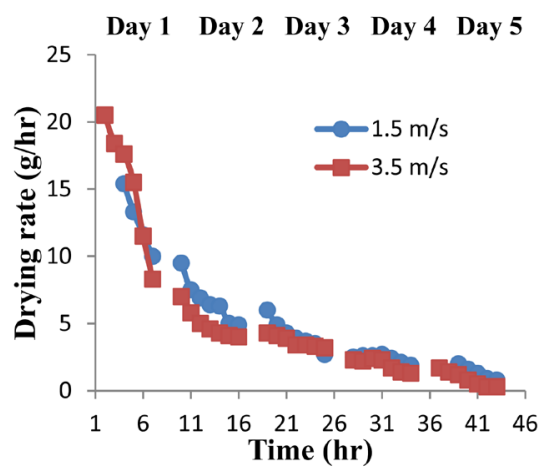

(b)

Figure 6. Variation of catfish (a) moisture content (b) drying rate with time during wet season.

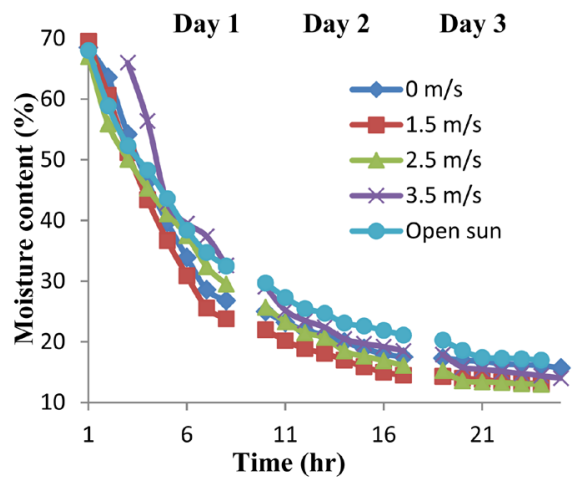

(a)

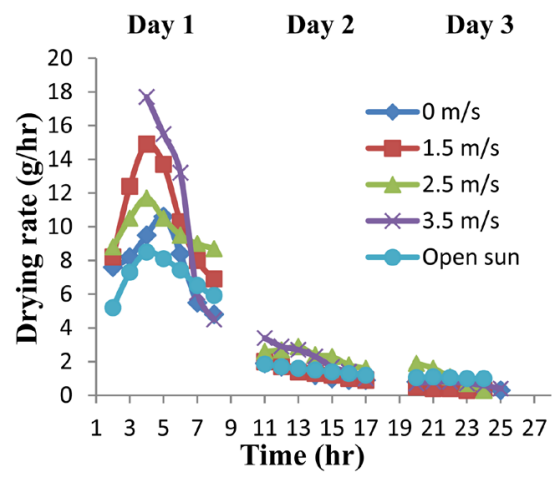

(b)

Figure 7. Variation of tilapia fish (a) moisture content (b) drying rate with time during the dry season.

drying temperature and low relative humidity which facilitates easy migration of interstitial water to the surface of the drying fish. High relative humidity decreases the moisture absorption potential of the air [9]. The plot of the drying rates also reveals that fish like any other agriculture product exhibit falling rate drying period. This confirms previous works done by Micheal et al. [14] and Mujaffar [24]. 


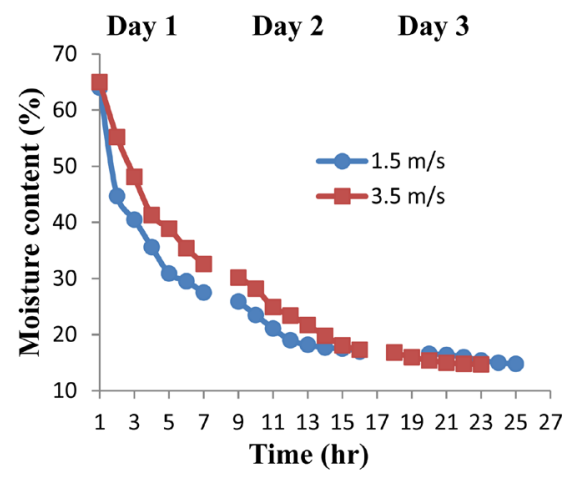

(a)

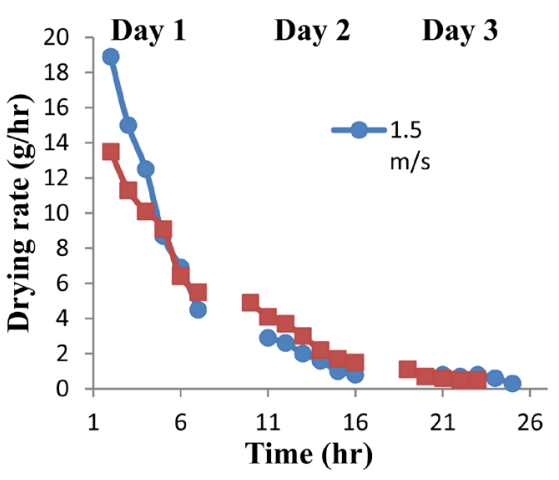

(b)

Figure 8. Variation of tilapia fish (a) moisture content (b) drying rate with time during the wet season.

\subsection{Effect of Fan Speed on the Dryer Performance}

Fast removal of moisture was observed on the first day of the drying process and was majorly due to drying of surface water in which air movement was by far the greatest factor. The influence of air flow on the liquid water inside the materials begins to diminish because movement of air was no longer in direct contact with the evaporating water and the different fan speeds considered has no significant effect on the drying time. During the drying process of catfish at $0 \mathrm{~m} / \mathrm{s}$, slow drop in moisture content was observed on first two days which was as a result of moisture lagging and high drying air humidity. Condensation moisture was experienced due to poor evacuation of moist air from the dyer. As the air inside the dryer gets heated, it becomes denser and tends to move out of the dryer towards the low pressure area, but not enough to speed up the drying rates. For tilapia fish, moist lagging was very minimal and no moisture condensation occurred and this can be attributed to the amount of crude fat in the fish sample, measured before drying which was lesser compared to that of catfish. At 1.5, 2.5, and $3.5 \mathrm{~m} / \mathrm{s}$, good evacuation of moist air was observed in the dryer, no moisture lagging and condensation.

No convective cooling inside in the dryer at $0 \mathrm{~m} / \mathrm{s}$ due to natural convective mode of drying, so the air temperature recorded between 12:00 pm and 3:00 pm were high (Above $60^{\circ} \mathrm{C}$ ) and according to Ames et al. (1999), fish should not be subjected to temperature as high as $60^{\circ} \mathrm{C}$ to avoid fish cooking and lose of amino acid. The drying air temperature, solar radiation and relative humidity recorded during the drying process of the fish species ranged between $34.2^{\circ} \mathrm{C}$ and $63.4^{\circ} \mathrm{C}$, 321 and $990 \mathrm{~W} / \mathrm{m}^{2}$ and between $18.6 \%$ and $60.1 \%$, respectively. At $1.5 \mathrm{~m} / \mathrm{s}$, they ranged between $35.2^{\circ} \mathrm{C}$ and $52.9^{\circ} \mathrm{C}, 213$ and $929 \mathrm{~W} / \mathrm{m}^{2}$ and between $18.1 \%$ and $68.8 \%$, respectively. At $2.5 \mathrm{~m} / \mathrm{s}$, they ranged between $31.5^{\circ} \mathrm{C}$ and $54.5^{\circ} \mathrm{C}, 215$ and $985 \mathrm{~W} / \mathrm{m}^{2}$ and between $19.5 \%$ and $55.8 \%$, respectively. At $3.5 \mathrm{~m} / \mathrm{s}$, they ranged between $35.5^{\circ} \mathrm{C}$ and $55.5^{\circ} \mathrm{C}, 219$ and $981 \mathrm{~W} / \mathrm{m}^{2}$ and between $11.5 \%$ and $64.5 \%$, respectively. From these result it was observed that the higher the fan speed, the more the convective cooling and the lower the drying air temperature. The fan speeds has no significant effect on the drying time but when these results were 
compared with the solar radiation recorded it was observed that fan speed at 3.5 $\mathrm{m} / \mathrm{s}$ has more effect on the drying rates.

\subsection{Effect of Species of Fish on the Performance of the Dryer}

In Figures 5-8, it was observed that the tilapia fish samples dried faster than catfish despite higher initial moisture content using the dryer. These observations can be attributed to the porosity level in the fish muscle which enhanced the rate at which water was released from the fish, temperature sensitivity of the fish species and slower rate of evaporation of bound water observed when drying catfish samples compared to tilapia fish. From the result obtained the catfish samples took an average of 32 hours intermittently before safe moisture content was achieved while tilapia fish took an average of 20 hours intermittently. The difference was significant on the first day and the moisture content of catfish samples at the end of the drying process on the first day was averagely $38 \%$ from initial moisture content of $57.8 \%$ at solar radiation and drying air temperature range, between 213 and $990 \mathrm{~W} / \mathrm{m}^{2}$ and between $34.2^{\circ} \mathrm{C}$ and $63.4^{\circ} \mathrm{C}$, respectively while for tilapia fish, it was averagely $28.1 \%$ from initial moisture content of $68 \%$ at solar radiation and drying air temperature range, between 220 and $1106 \mathrm{~W} / \mathrm{m}^{2}$ and between $32.5^{\circ} \mathrm{C}$ and $59.2^{\circ} \mathrm{C}$, respectively.

\subsection{Effect of Season on the Performance of the Dryer}

In Figures 5-8, the performance of the dryer during the dry season was more efficient and safer for the fish samples than the performance of the dryer during the wet season. High solar radiation and high drying air temperature in the dryer were recorded during the dry season which enhanced the drying rate and the values obtained shows that the designed solar dryer has the capacity of heating air to $6^{\circ} \mathrm{C}-35^{\circ} \mathrm{C}$ above ambient temperature depending on the value of intensity of solar radiation while the solar radiation and drying air temperatures recorded during the wet season were low due to rain that fell at the early hour of the first day of the drying days but for subsequent days, similar readings as drying season were recorded. Besides, high temperatures recorded correspond to the period when the global solar radiation is maximum at day time and are in agreement with several other authors [9].

During the dry season it took averagely 32 hours of intermittent drying for catfish samples to reach safe moisture content, averagely $13.97 \%$ while it took averagely 37 hours to reach moisture content of $15.4 \%$ during the wet season. The average final moisture content achieved during the dry season was $1.77 \%$ and during the wet season was 3.2\% more compared with that achieved by Micheal et al. [14] (12.2\% final moisture content with an electric kiln at $55^{\circ} \mathrm{C}$ within 35 hours). Due to the poor weather condition on the first day during the wet season, the head was almost spoiling and were removed from the experiment the following day. The results obtained for both season were compared and it was observed that to avoid any trace of fish spoilage the initial moisture content of catfish should be reduced to at least $45 \%$ on the first day of the drying process 
and this is better achieved during the dry season. The drying air temperature, solar radiation and relative humidity recorded during the drying process in dry season ranged between $34.2^{\circ} \mathrm{C}$ and $63.4^{\circ} \mathrm{C}, 321$ and $990 \mathrm{~W} / \mathrm{m}^{2}$ and between $18.6 \%$ and $60.1 \%$, respectively while during the wet season, they ranged between $30.3^{\circ} \mathrm{C}$ and $49.2^{\circ} \mathrm{C}, 290$ and $895 \mathrm{~W} / \mathrm{m}^{2}$ and between $26.2 \%$ and $70.1 \%$, respectively. It took averagely 20 hours for tilapia fish samples during the dry season to reach average moisture content of $13.35 \%$ while it took averagely 21 hours to reach moisture content of $15.5 \%$ during the wet season. The drying air temperature, solar radiation and relative humidity recorded during the dry season ranged between $37.5^{\circ} \mathrm{C}$ and $62.1^{\circ} \mathrm{C}, 220$ and $980 \mathrm{~W} / \mathrm{m}^{2}$ and between $20.1 \%$ and $59.2 \%$, respectively while during the wet season, they ranged between $29.0^{\circ} \mathrm{C}$ and $50.9^{\circ} \mathrm{C}, 150$ and $960 \mathrm{~W} / \mathrm{m}^{2}$ and between $26.8 \%$ and $70.3 \%$, respectively. The experimental results show that the best time to use the dryer is the dry season to avoid trace of fish spoilage.

\subsection{Comparison of the Dryer Performance with That of Open Sun Drying}

The results indicates prospect for better performance of the dryer than open sun drying and also shows that the solar dryer is a better alternative technology in rural location in order to avoid disadvantages of convectional open sun drying method. The open sun drying method was carried out on the same day with fish samples dried at $2.5 \mathrm{~m} / \mathrm{s}$ simultaneously during the dry season and the drying process was ended when the drying weight of the dryer dried sample was no longer significant.

The final moisture content and overall drying rate of catfish openly sun dried was $20.5 \%$ and $4.09 \mathrm{~g} / \mathrm{hr}$, respectively while they were $14.8 \%$ and $6.96 \mathrm{~g} / \mathrm{hr}$, respectively for the dryer dried sample. The ambient temperature ranged between $27^{\circ} \mathrm{C}$ and $38^{\circ} \mathrm{C}$ while the dryer temperature ranged between $31.5^{\circ} \mathrm{C}$ and $54.5^{\circ} \mathrm{C}$. The final moisture content and overall drying rate of tilapia fish openly sun dried was $17.0 \%$ and $4.09 \mathrm{~g} / \mathrm{hr}$, respectively while they were $14.6 \%$ and $5.11 \mathrm{~g} / \mathrm{hr}$, respectively for the dryer dried sample. The ambient temperature ranged between $28^{\circ} \mathrm{C}$ and $39.8^{\circ} \mathrm{C}$. The low drying rate recorded was as the result of poor air movement around the fish samples, low ambient temperature and high ambient relative humidity recorded compared to the dryer.

\subsection{Drying Efficiency}

Figure 8 shows the variation in drying efficiency of the dryer with time during the dry season. Maximum drying efficiency of $74.3 \%$ for catfish and $65 \%$ for tilapia fish was recorded at $3.5 \mathrm{~m} / \mathrm{s}$ fan speed during the drying process. Figure 9 show the variation in drying efficiency with time for both catfish and tilapia fish at $1.5 \mathrm{~m} / \mathrm{s}$ and $3.5 \mathrm{~m} / \mathrm{s}$ fan speed during the wet season. Maximum average drying efficiency of the dryer was $61 \%$ when drying catfish and it was obtained at $3.5 \mathrm{~m} / \mathrm{s}$ while it was $52 \%$ when drying tilapia fish and was obtained at $1.5 \mathrm{~m} / \mathrm{s}$. From the graph it was observed that the drying efficiency of the dryer decreases 


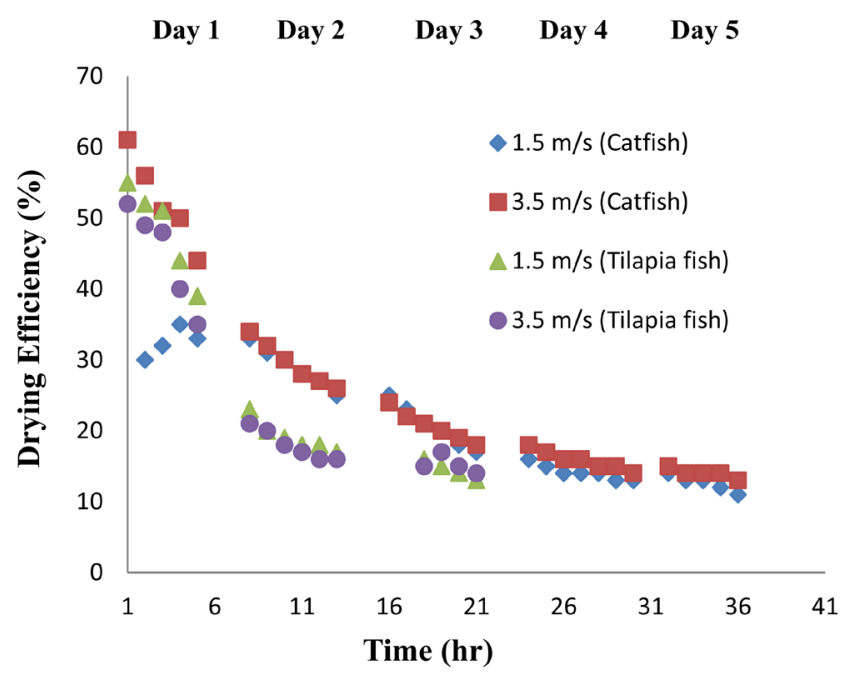

Figure 9. Variation in drying efficiency with time for both catfish and tilapia fish at $1.5 \mathrm{~m} / \mathrm{s}$ and $3.5 \mathrm{~m} / \mathrm{s}$ fan speed during the wet season.

as the loss in weight of the fish samples decreases and as the drying time increases.

\subsection{Effects of Drying on the Proximate Composition of the Fish Species}

The proximate composition of the fish species before drying is presented in $\mathrm{Ta}$ ble 1 while the proximate composition after drying is presented in Table 2 \& Table 3 for catfish and tilapia fish, respectively. Protein and crude fat are the major nutrients in fish and their levels help to define the nutritional status of the particular fish species [25]. The proximate composition result before drying shows that Catfish and tilapia fish examined belong to a high protein category because their protein value was within the range of 30\% - 38\% and they both had crude fat (lipid) greater than 5\%. According to Stan by [26], fishes with lipid content below $5 \%$ are lean. The observed range of ash content (A.C) indicated that both species are good source of mineral such as calcium, potassium, zinc, iron and magnesium and it should also be noted that the loss of lipid (Crude fat) is due to lipid oxidation at high temperature [14]. It was observed that the ash content, crude fat and crude protein reduces after the drying process while the carbohydrate value increases and this was in agreement with Micheal et al. [14] which noted that the crude fat content, crude protein and crude ash decreases due to increase in temperature. Using statistical approach, no significant difference in proximate composition of the two fish species at fan speeds considered $(\mathrm{P}<0.05)$ but there was significant difference in proximate composition before drying and after drying $(\mathrm{P}<0.05)$.

\section{Conclusion}

The moisture diffusion was the physical dominant mechanism that governs the movement of moisture from within the fish species. Drying air temperature and 
Table 1. Proximate compositions of the two samples for the two species of fish considered.

\begin{tabular}{ccc}
\hline Prox. Comp. & Catfish & Tilapia fish \\
\hline Moisture content (\%) & $57.60 \pm 0.90$ & $69.50 \pm 1.2$ \\
Crude fat (\%) & $25.48 \pm 0.41$ & $23.99 \pm 0.06$ \\
Ash content (\%) & $27.80 \pm 0.20$ & $25.77 \pm 0.43$ \\
Crude fiber (\%) & $0.75 \pm 0.01$ & $0.55 \pm 0.02$ \\
Crude protein (\%) & $37.24 \pm 0.30$ & $39.10 \pm 0.68$ \\
Carbohydrate (\%) & $7.34 \pm 0.08$ & $7.68 \pm 0.10$ \\
\hline
\end{tabular}

Table 2. Variation in $\%$ composition of the quality of the catfish samples.

\begin{tabular}{ccccccc}
\hline & M. C (\%) & C.fat (\%) & A.C (\%) & C. fiber (\%) & C. protein (\%) & Carb. (\%) \\
\hline $0 \mathrm{~m} / \mathrm{s}$ & $17.60 \pm 0.14$ & $18.10 \pm 0.21$ & $16.34 \pm 0.15$ & $0.69 \pm 0.04$ & $32.68 \pm 0.27$ & $13.45 \pm 0.09$ \\
$1.5 \mathrm{~m} / \mathrm{s}$ & $11.99 \pm 0.25$ & $18.55 \pm 0.24$ & $16.99 \pm 0.10$ & $0.76 \pm 0.01$ & $33.15 \pm 0.31$ & $10.98 \pm 0.07$ \\
$2.5 \mathrm{~m} / \mathrm{s}$ & $13.17 \pm 0.10$ & $19.15 \pm 0.31$ & $17.28 \pm 0.13$ & $0.81 \pm 0.01$ & $33.85 \pm 0.28$ & $11.55 \pm 0.09$ \\
$3.5 \mathrm{~m} / \mathrm{s}$ & $12.35 \pm 0.20$ & $18.90 \pm 0.35$ & $17.12 \pm 0.12$ & $0.79 \pm 0.01$ & $33.50 \pm 0.32$ & $11.12 \pm 0.12$ \\
O.S & $19.50 \pm 0.23$ & $19.31 \pm 0.33$ & $18.03 \pm 0.07$ & $0.79 \pm 0.01$ & $34.15 \pm 0.40$ & $13.88 \pm 0.04$ \\
\hline
\end{tabular}

Table 3. Variation in $\%$ composition of the quality of the catfish samples.

\begin{tabular}{ccccccc}
\hline & M. C (\%) & C.fat (\%) & A.C (\%) & C. fiber (\%) & C. protein (\%) & Carb. (\%) \\
\hline $0 \mathrm{~m} / \mathrm{s}$ & $15.7 \pm 0.11$ & $16.42 \pm 0.31$ & $16.76 \pm 0.13$ & $0.69 \pm 0.04$ & $35.29 \pm 0.28$ & $13.25 \pm 0.19$ \\
$1.5 \mathrm{~m} / \mathrm{s}$ & $12.1 \pm 0.22$ & $17.05 \pm 0.41$ & $16.02 \pm 0.08$ & $0.66 \pm 0.03$ & $36.10 \pm 0.37$ & $11.34 \pm 0.14$ \\
$2.5 \mathrm{~m} / \mathrm{s}$ & $11.28 \pm 0.15$ & $17.52 \pm 0.21$ & $16.24 \pm 0.24$ & $0.77 \pm 0.01$ & $36.78 \pm 0.21$ & $12.10 \pm 0.24$ \\
$3.5 \mathrm{~m} / \mathrm{s}$ & $11.66 \pm 0.12$ & $17.45 \pm 0.33$ & $16.19 \pm 0.19$ & $0.69 \pm 0.03$ & $36.45 \pm 0.25$ & $12.00 \pm 0.20$ \\
O.S & $16.0 \pm 0.09$ & $17.94 \pm 0.10$ & $15.94 \pm 0.10$ & $0.53 \pm 0.06$ & $33.94 \pm 0.21$ & $17.97 \pm 0.37$ \\
\hline
\end{tabular}

${ }^{*}$ O.S-Open sun.

air humidity are the main factors controlling the drying performance and the higher the drying air temperature the higher the drying rate. High drying rate and high drop in moisture content were observed on the first day of each of the drying process. To avoid moisture lagging in the dryer, forced convective drying method should be employed. The experimental results show that the best time to use the dryer is the dry season to avoid any trace of fish spoilage and at least $45 \%$ of the initial moisture content of catfish should be removed on the first day to prevent fish spoilage when using direct solar dryer without thermal storage and this is better achieved during the dry season. Maximum drying efficiency (74.3\%) was recorded at $3.5 \mathrm{~m} / \mathrm{s}$ fan speed during the dry season. From the study, the solar dryer has proven to be a better alternative technology and a useful tool for the preservation of the considered fish species to increase the shelf life and market value in order to avoid disadvantages of open sun method of drying fish. 


\section{References}

[1] Lagler, K.F., Bardarch, J.E., Miller, R.R. and Passino, D.R. (1997) Ichthyology. 2nd Edition, John Wiley and Sons, New York.

[2] Abila, R.O. (2003) Food Safety in Food Security and Food Trade: Case Study: Kenyan Fish Exports. 2020 Vision for Food, Agriculture and Environment, International Food Policy Research Institute, Washington DC.

[3] Garg, H.P. and Prakash, J. (2000) Solar Energy: Fundamentals and Applications. 1st Revised Edition, Tata MCgraw Hill Publishers, New Delhi.

[4] Gram, L. and Dalgaard, P. (2002) Fish Spoilage Bacteria Problems and Solution. Current Opinion in Biotechnology, 13, 262-266. https://doi.org/10.1016/S0958-1669(02)00309-9

[5] Mustayen, A.G., Mekhilef, S. and Saidur, R. (2014) Performance Study of Different Solar Dryers: A Review. Journal of Renewable and Sustainable Energy, 34, 463-470. https://doi.org/10.1016/j.rser.2014.03.020

[6] Bala, B.K. and Woods, J.L. (1994) Simulation of Indirect Natural Convection Solar Drying of Rough Ric. Solar Energy Journal, 53, 259-266. https://doi.org/10.1016/0038-092X(94)90632-7

[7] Bala, B.K. and Woods, J.L. (1995) Optimization of a Natural Convection Solar Drying System. Journal of Energy, 20, 285-294.

https://doi.org/10.1016/0360-5442(94)00083-F

[8] Alonge, O.I. and Obayopo, S.O. (2017) CFD and Experimental Analysis of Direct Solar Dryer for Fish. Unpublished paper.

[9] Kituu, G.M., Shitanda, D., Kanali, C.L., Mailutha, J.T., Njoroje, C.K., Wainaina, J.K. and Silayo, V.K. (2010) Thin Layer Drying Model for Simulating the Drying of Tilapia Fish in a Solar Tunnel Dryer. Journal of Food Engineering, 98, 325-331. https://doi.org/10.1016/j.jfoodeng.2010.01.009

[10] Bala, B.K. and Mondols, M.R. (2001) Experimental Investigation on Solar Drying of Fish Using Solar Tunnel Dryer. Drying Technology: An International Journal, 19, 247-436. https://doi.org/10.1081/DRT-100102915

[11] Sengar, S.H, Khandetod, Y.P. and Mohod, A.G. (2009) Low Cost Solar Dryer for Fish. African Journal of Environmental Science and Technology, 3, 265-271.

[12] Komolafe, C.A., Ogunleye, I.O. and Adejumo, A.O. (2011) Design and Fabrication of a Convective Fish Dryer. Pacific Journal of Science and Technology, 12, 1.

[13] Shi, Q.-L., Xue, C.-H., Zhao, Y., Li, Z.-J., Wang, X.-Y. and Luan, D.-L. (2008) Optimization of Processing Parameters of Horse Mackerel (Trachus japonicus) Dried in a Heat Pump Dehumidifier Using Response Surface Methodology. Journal of Food Engineering, 87, 74-81. https://doi.org/10.1016/j.jfoodeng.2007.11.010

[14] Micheal, O., Adesoji, O. and Shuaeeb, O. (2012) Drying of African Catfish; Effects of Some Drying Parameters on the Drying Rate and Quality of African Catfish. Lap Lambert Academic Publishing, Riga.

[15] Owolarafe, O.K., Obayopo, S.O., Amarachi, O.A., Babatunde, O. and Ologunro, O.A. (2011) Development and Performance Evaluation of an Okra Drying Machine. Research Journal of Applied Sciences, Engineering and Technology, 3, 914-922.

[16] Youcef-Ali, S.H., Messaoudi, J.Y., Desmons, A. and Le Ray, M. (2001) Determination of the Average Coefficient of Internal Moisture Transfer during the Drying of a Thin Bed of Potato Slices. Journal of Food Engineering, 48, 95-101. https://doi.org/10.1016/S0260-8774(00)00123-0 
[17] Brooker, D.B., Bakker-Arkema, F.W. and Hall, C.W. (1992) Drying and Storage of Grains and Oilseeds. Springer Science \& Business Media, Berlin.

[18] Hernandez, J.A., Pavon, G. and Garcia, M.A. (2000) Analytical Solution of Mass Transfer Equation Considering Shrinkage for Modeling Food Drying Kinetics. Journal of Food Engineering, 45, 1-10. https://doi.org/10.1016/S0260-8774(00)00033-9

[19] Ekechukwu, O.V. (1999) Review of Solar-Energy Drying Systems I: An Overview of Drying Principles and Theory. Energy Conversion \& Management, 40, 593-613. https://doi.org/10.1016/S0196-8904(98)00092-2

[20] AOAC (2000) Official Method of Analysis of the Association of Official Analytical Chemists. 16th Edition, Virgina.

[21] Yusheng, Z. and Poulsen, K.P. (1988) Diffusion in Potato Drying. Journal of Food Engineering, 7, 249-262. https://doi.org/10.1016/0260-8774(88)90007-6

[22] Sankat, C.K. and Mujaffar, S. (2006) Modelling the Drying Behaviour of Salted Catfish Fillets. 15th International Drying Symposium, Budapest, 20-23 August 2006, 1-7.

[23] Kilic, D. and Tiwari, G. (2009) Thermal Aspects of Open Sun Drying of Various Crops. Energy Journal, 28, 37-54.

[24] Mujaffar, S. and Sankat, K.C. (2005) The Mathematical Modeling of the Osmotic Dehydration of Shark Fillets at Different Brine Temperatures. International Journal of Food Science Technology, 40, 1-12.

[25] Bolawa, O., Gbenle, G.O., Ayodele, S.O. and Adewusi, O.R. (2001) Proximate Composition Properties of Different Species Obtained from Lagos Nigeria. University of Lagos, Lagos.

[26] Stanby, M.E. (1982) Properties of Fish Oils and Their Application to Handling of Fish and to Nutritional and Industrial Use. In: Martin, R.E., Flick, G.J., Hebard, C.E. and Ward, D.R., Eds., Chemistry and Biochemistry of Marine Food Product, Ayi Publishing Co., 75-92. 